GEORG RITZER

Kirchliche Pädagogische Hochschule Wien/Krems

Forum Pedagogiczne

Wiedeń (Austria)

INES M. BREINBAUER

$2016 / 2$ cz. 1

Wpłynęło: 10.03 .2016 Zatwierdzono do druku: 24.05.2016 DOI: $10.21697 / \mathrm{fp} .2016 .2 .04$

Wiener Univeristät

Wiedeń (Austria)

HENNING SCHLUSS

Wiener Univeristät

Wiedeń (Austria)

THOMAS KROBATH

Kirchliche Pädagogische Hochschule Wien/Krems

Wiedeń (Austria)

\title{
ETIK-INTERNATIONAL WIEDEŃ. PROBLEMY BADAWCZE, PRZEPROWADZONE BADANIE I ANALIZA WYNIKÓW'
}

Streszczenie: Etyka w Austrii, podobnie jak w większości krajów Europy, ma w publicznym systemie edukacji szkolnej status przedmiotu alternatywnego wobec religii. Mimo że stan taki trwa od ponad dwóch dziesiątek lat, brakuje woli politycznej i społecznej, żeby go zmienić. W niniejszym artykule zaprezentowano badanie ETiK-International, które zostało przeprowadzone w Wiedniu w 2014 roku przez zespół złożony z naukowców pochodzących z Wiener Univerisität i Kirchliche Pädagogische Hochschule Wien/Krems.

Artykuł składa się z czterech rozdziałów. W pierwszym scharakteryzowano prawne i społeczno-kulturowe determinanty prowadzenia lekcji etyki i religii w Austrii. W drugim rozdziale zaprezentowano problemy badawcze podjęte w przeprowadzonym badaniu ETiKInternational. W dwóch kolejnych omówiono wyniki ilościowe (rozdział trzeci) i jakościowe (rozdział czwarty), jakie uzyskano w 11 wybranych wiedeńskich szkołach średnich.

Słowa kluczowe: ETiK-International, kompetencja moralno-etyczna, badanie ilościowe, badanie jakościowe.

${ }^{1}$ [Tekst został opublikowany w języku niemieckim pt. ETiK-International-Wien. Ethikunterricht und Religionsunterricht in Österreich. Forschungsfragen, Ansatz und Befunde w: Benner, Nikolova 2016, s. 217-226. Publikacje przywoływane i cytowane w tym artykule są podawane w wersji polskiej, o ile taka istnieje. Pochodzące od tłumacza uzupełnienia i dopowiedzenia umieszczono w nawiasach kwadratowych i opatrzono dopiskiem „dop. D.S.”]. 
Idea przeprowadzenia w Wiedniu badania ETiK-International powstała w związku z dwoma wydarzeniami. Pierwszym z nich był Tag der Forschung (Dzień Badań), który po raz pierwszy odbył się na Kirchliche Pädagogische Hochschule Wien/ Krems (KPH) w dniu 8 marca 2013 roku. Podczas tego dnia jeden z głównych referatów wygłosił Dietrich Benner, który przedstawił koncepcję pedagogiki ogólnej jako dyscypliny czynnie angażującej się w badanie rzeczywistości edukacyjnej. Swoje wystąpienie zilustrował wstępnymi wynikami dobiegającego wówczas końca berlińskiego projektu ETiK, wskazując jednocześnie na możliwość przeprowadzenia podobnego badania w Austrii (Benner 2014a).

Drugim wydarzeniem, które legło u początków wiedeńskiego badania, było przyjęcie przez D. Bennera w roku akademickim 2013/2014 obowiązków profesora wizytującego (Gastprofessur) w Wiener Universität (WU). W związku z tym w semestrze letnim wygłosił on na tamtejszym Wydziale Filozofii i Nauk o Kształceniu serię wykładów na temat związków zachodzących między kształceniem, moralnością i demokracją (Benner i in. 2015). Następnie ukonstytuował się zespół naukowców złożony z pracowników obu uczelni, a mianowicie KPH - Georg Ritzer i Thomas Krobath, i WU - Ines M. Breinbauer i Henning Schluss, którzy wyrazili gotowość współpracy w celu przeniesienia na grunt austriacki opracowanego w Berlinie Testu Kompetencji Moralno-Etycznej Piętnastolatków (TKM-EP) i sprawdzenia jego trafności.

Poniższe rozważania ujęte są $\mathrm{w}$ czterech rozdziałach. W pierwszym zostaną skrótowo omówione prawne i społeczno-kulturowe determinanty prowadzenia lekcji etyki i religii w Austrii. Drugi rozdział zawiera prezentację głównych problemów, jakie podjęto w wiedeńskim badaniu ETiK-International. Dwa następne rozdziały poświęcono wynikom uzyskanym w dwóch rodzajach badania - studium ilościowym (rozdział trzeci) i studium jakościowym (rozdział czwarty).

\section{Uwarunkowania prawne i społeczno-kulturowe lekcji etyki i religii w Austrii}

Od początku lat 9o. minionego stulecia coraz więcej uczniów i uczennic w austriackich szkołach rezygnowało z konfesyjnie prowadzonego nauczania religii lub jako osoby bezwyznaniowe w ogóle nie uczestniczyło w lekcjach z tego przedmiotu. Początkowo uczniom tym dyrekcje szkół nie proponowały żadnych zajęć alternatywnych. Ponieważ jednak zadaniem edukacji szkolnej jest wychowanie oparte na wartościach, jak to jednoznacznie wynika $\mathrm{z}$ austriackiego prawa oświatowego ${ }^{2}, \mathrm{co}$

2 W głównym austriackim dokumencie oświatowym Schulorganisationsgesetz $\mathrm{w} \$ 2$ ust. 1 stwierdza się m.in.: „Szkoła austriacka ma za zadanie współdziałać w rozwijaniu u młodzieży zdolności w zakresie wartości etycznych, religijnych i społecznych oraz wartości prawdy, dobra i piękna przez odpowiednio dostosowane do poziomu rozwoju i drogi kształcenia nauczanie szkolne. Ma wyposażyć młodzież w wiedzę i umiejętności, wymagane do życia i wykonywania przyszłego zawodu oraz przygotować do samodzielnego kształcenia” (Schulorganisationsgesetz, dostępny na stronie: https://www.ris.bka.gv.at/GeltendeFassung.wxe?Abfrage=Bundesnormen\&Gesetze snummer $=10009265$, otwarto 14.07.2015). 
do tej pory było realizowane przede wszystkim na lekcjach religii ${ }^{3}$, zaczęto zastanawiać się na forum publicznym nad tym, w jaki sposób można zadość uczynić temu zadaniu wobec uczniów i uczennic nieuczestniczących w zajęciach z religii. W roku szkolnym 1997/1998 w wybranych ośmiu austriackich szkołach średnich rozpoczął się eksperyment szkolny pod nazwą „Etyka”. Objęto nim uczniów znajdujących się na ostatnim etapie kształcenia ogólnego (Sekundarstufe II) i przygotowujących się do egzaminu maturalnego. Etykę zaproponowano im zamiast religii jako obowiązkowy przedmiot do wyboru.

Inny eksperyment, ale o podobnym charakterze, przeprowadzono $\mathrm{w}$ roku szkolnym 2012/2013. Tym razem wzięło w nim udział znacznie więcej placówek oświatowych z całej Austrii; łącznie 223 szkół średnich ogólnokształcących (Allgemeinbildende Höhere Schulen - AHS) i zawodowych (Berufliche Höhere Schulen - BHS). W tym eksperymencie uczęszczanie na zajęcia $\mathrm{z}$ etyki było obowiązkiem wszystkich uczniów i uczennic, którzy z jakichkolwiek powodów nie uczestniczyli w lekcjach religii (Schmied 2012).

Ponieważ w obu wskazanych powyżej przypadkach chodziło o eksperymenty szkolne, ich inicjatorzy nie posługiwali się szczegółowymi programami nauczania etyki, lecz jedynie ogólnymi wskazaniami odnośnie do sposobu prowadzenia tych zajęć i ich zakresu tematycznego. Wskazania te przygotowano w oparciu o programy nauczania obowiązujące w sąsiednim kraju - Republice Federalnej Niemiec. W Austrii zostały one tylko nieznacznie zmodyfikowane. W tym kontekście nie może dziwić fakt, że wszystkie austriackie „programy” nauczania etyki są w wysokim stopniu jednorodne, a nawet identyczne.

Jeżeli chodzi o kształcenie nauczycieli etyki, to do tej pory prowadziły je zarówno państwowe, jak i kościelne wyższe szkoły pedagogiczne (Pädagogische Hochschulen) w formie studiów podyplomowych, za które można było uzyskać 30 punktów ECTS (Schmied 2012, s. 5). Zwracamy uwagę na to dlatego, że wyższe szkoły pedagogiczne w Austrii nie mają uprawnień do kształcenia nauczycieli przeznaczonych do pracy w placówkach oświatowych na ostatnim etapie kształcenia ogólnego. To zadanie jest zarezerwowane wyłącznie dla wydziałów pedagogicznych na uniwersytetach. W przypadku etyki zrezygnowano z tego obostrzenia, mimo że wszystkie dotychczasowe eksperymenty szkolne dotyczące lekcji etyki były prowadzone na tym właśnie poziomie. Jedyny wyjątek w zakresie przygotowania kandydatów do zawodu nauczyciela etyki stanowi Wydział Filozofii i Nauki o Kształceniu WU, który proponuje uniwersytecki kurs etyki. Jego uczestnicy mogą uzyskać 96 punktów ECTS. Ta oferta jednak jest czasowo ograniczona do 2016 roku (Universitätslehrgang „Ethik”). Wówczas to mija termin akredytacji tego kierunku kształcenia.

W skali całej Austrii lekcje etyki były dwukrotnie, jak do tej pory, przedmiotem badań ewaluacyjnych. Oba badania przeprowadził Anton A. Bucher. Obszerniejsze

3 Odnośnie do problematyki wychowania do wartości w ramach konfesyjnych lekcji religii zob. Schluss 2011. 
studium powstało na początku bieżącego millenium (Bucher $2001^{4}$ ). W 2013 roku autor wrócił do tego problemu, jednak tym razem owoc jego analiz przypomina raczej paidoyer za wprowadzeniem obowiązkowych lekcji etyki niż publikację o charakterze naukowym. A.A. Bucher przeprowadził ankiety wśród uczniów, starając się $\mathrm{z}$ ich pomocą przekonać o korzyściach wynikających $\mathrm{z}$ uczęszczania na ten przedmiot (Bucher 2014). W każdym razie obie prace mogą służyć za swoistą fotografię rozwoju problematyki nauczania etyki w Austrii.

To, że w Austrii nauczanie etyki odbywa się tak długo w postaci eksperymentów edukacyjnych, nie przybierając formy „normalnych” lekcji szkolnych, nie jest sprawą samo przez się zrozumiałą. Powodów takiego stanu rzeczy należy dopatrywać się w oporze politycznym i społecznym, który towarzyszy nie tylko wspomnianym powyżej eksperymentom, lecz również kwestii moralności w ogóle. Zwłaszcza przedstawiciele Kościoła katolickiego i Austriackiej Partii Ludowej (Österreichische Volkspartei - ÖVP) sprzeciwiają się wprowadzeniu do szkół przedmiotu etyka, obawiając się zapewne konkurencji dla lekcji religii. Jednak już w 1993 roku dyrektorzy katolickich urzędów szkolnych (katholische Schulamtsleiter), które działają przy kuriach biskupich i są odpowiedzialne za szkoły prowadzone przez katolickie organy prowadzące, opowiedzieli się za potrzebą organizowania lekcji etyki dla tych uczniów i uczennic, którzy (również w szkołach katolickich) rezygnują z lekcji religii (Bucher 2001, s. 19 i n.). To stanowisko zostało przypomniane i oficjalnie potwierdzone w związku z wyborami parlamentarnymi w 2011 roku (Ethikunterricht: Klare Position der katholischen Kirche). Przy tej samej okazji wiele innych osób - pedagodzy, naukowcy i ludzie uznawani za autorytety społeczne wsparło działania na rzecz wprowadzenia edukacji etycznej (Schmied 2012, s. 12-18).

Oprócz znanego już modelu eksperymentu pedagogicznego (etyka jako alternatywny przedmiot obowiązkowy do wyboru zamiast lekcji religii), w Austrii dyskutuje się nad dwoma innymi jeszcze sposobami prowadzenia zajęć z tego przedmiotu, a mianowicie niezależnym dodatkowym przedmiotem obowiązkowym (w wymiarze jednej lub dwóch godzin lekcyjnych tygodniowo) lub częścią programu nauczania w ramach innego istniejącego już przedmiotu obowiązkowego, „który podlega bezpośredniej kontroli Ministerstwa Kształcenia (Bildungsministerium) i o którym opinia publiczna i parlament są informowani wprost za pomocą raportu wspomnianego ministerstwa" (Schmied 2012, s. 3). Wzmiankowany raport wywołał po wyborach parlamentarnych ożywioną debatę publiczną, która jednakże nie spowodowała żadnej zmiany w prawnym status quo lekcji etyki.

Niebagatelną rolę w całej sprawie odgrywają również koszty wprowadzenia do szkół etyki. Szacunkowo zostały one wyliczone przez Ministerstwo Kształcenia i, jak podaje Claudia Schmied, najdroższy okazał się wariant przewidujący dwustopniowe nauczanie etyki jako przedmiotu obowiązkowego dla wszystkich uczniów i uczennic

4 Skrócona wersja wyników uzyskanych w 2001 roku znajduje się na następującej stronie: https:// www.sbg.ac.at/pth/people/bucher/evaluation.htm, otwarto 14.07.2015. 
(Schmied 2012, s. 23). W skali całego kraju na ten cel należało by wydać około 105 mln euro. Natomiast z perspektywy wydatków budżetowych najkorzystniejszy byłby ostatni z omówionych powyżej wariantów, a mianowicie etyka jako część programu nauczania w ramach innego istniejącego już przedmiotu obowiązkowego. Wówczas prognoza wydatków opiewałaby na około $33 \mathrm{mln}$ euro rocznie (Schmied 2012, s. 27).

W nawiązaniu do trzech propozycji (modeli) nauczania etyki odbyła się w dniu 21 maja 2015 roku na WU debata $z$ udziałem przedstawicieli różnych wydziałów i zaproszonych gości ze świata kultury i polityki. Jej celem było danie nowego impulsu kwestii nauczania etyki, która od lat znajduje się w impasie. Mimo że wydarzenie to wzbudziło duże zainteresowanie społeczne, nie przyniosło jednak spodziewanego ożywienia w sprawie (Philosophisch-religiöse Bildung als Aufgabe der Schule?).

\section{Problemy badawcze wiedeńskiego badania ETiK-International}

To, że problemy i pytania etyczne i religijne należą do kompetencji publicznego systemu edukacji, uchodzi wśród ekspertów za rzecz bezsporną (Benner i in. 2009; Schluss 2010; Benner i in. 2011; Benner 2014b; Bucher 2014; Benner i in. 2015). Od pewnego czasu w odniesieniu do tych dwóch obszarów postuluje się również konieczność kształtowania w uczniach kompetencji, które w życiu społecznym wydają się niezbędne, przynajmniej w społeczeństwie tak niejednorodnym pod względem kulturowym i światopoglądowym jak Austria. Kompetencji tych nie da się po prostu posiąść przez zwykłe przebywanie ze sobą. Stąd w realizację tego zadania publicznego trzeba włączyć instytucje oświatowe. Na tym tle musi budzić niepokój wahanie wyrażane przez wielu przedstawicieli sfery politycznej w Austrii w związku z objęciem lekcjami etyki całej populacji dorastających. Jednak właśnie dlatego powinno zainteresować ich poszukiwanie odpowiedzi na pytanie: czy przy użyciu środków dostępnych oświacie publicznej można zapewnić wszystkim uczniom i uczennicom możliwość zdobycia głównych kompetencji moralno-etycznych, takich jak: podstawowa wiedza moralno-etyczna, kompetencja sądzenia moralno-etycznego i kompetencja projektowania tego samego rodzaju działania? Jest to pytanie wyrażające główny problem badawczy, jaki podjął się rozwiązać wiedeński zespół ETiK-International.

Na tle dyskusji przedstawionej w poprzednim rozdziale nad wprowadzeniem obligatoryjnego nauczania etyki należy mieć nadzieję, że naukowe projekty badawcze dotyczące tych zagadnień wzbudzą w Austrii zainteresowanie właściwych gremiów decyzyjnych, którym powinno zależeć na merytorycznym urzeczowieniu toczącego się od lat sporu wokół lekcji etyki. Nie można uznać bowiem za żadne rozwiązanie stanu, w którym ogromna rzesza austriackich uczniów i uczennic nie uczęszcza ani na lekcje religii, ani etyki. Uświadomienie w społeczeństwie tego problemu wyostrza jeszcze bardziej pytanie o to, gdzie kształtują się postawy moralne i prospołeczne uczniów.

Wiedeńskie badanie ETiK-International kierowało się do uczennic i uczniów szóstej klasy szkoły średniej (10 rok kształcenia), którzy uczestniczą w lekcjach 
etyki lub/i lekcjach religii (katolickich, ewangelickich, islamskich itd.) lub nie uczęszczają na żaden z tych dwóch przedmiotów. Celem badania było zgromadzenie danych świadczących o poziomie osiągnięć edukacyjnych uzyskiwanych w każdym z tym przedmiotów, a w przypadku uczniów „niezaangażowanych”, tj. nieuczęszczających ani na etykę, ani na religię, zamierzano określić ich kompetencje moralno-etyczne i religijne, ukształtowane niezależnie od zajęć szkolnych. Badanie przeprowadzono w dwóch wersjach - jako badania ilościowe i jakościowe. W obu przyjęto za podstawę ten sam zestaw pytań testowych przygotowany przez zespół z Berlina, modyfikując jednak zadanie, jakie mieli wykonać uczestniczy badania (poniżej będzie jeszcze o tym mowa). Wyniki uzyskane w każdym z rodzajów badań przedstawiono w osobnych rodziałach.

\section{Wybrane wyniki badania ilościowego}

Zanim przejdziemy do prezentacji danych ilościowych, zgromadzonych dzięki wypełnieniu przez uczniów zeszytów testowych, warto scharakteryzować narzędzie wykorzystane w badaniu ilościowym i opisać uczestników badania ze względu na następujące cechy etniczno-społeczno-kulturowe, a mianowicie: płeć, liczba książek posiadanych w biblioteczce domowej i język, jakim zazwyczaj uczniowie posługują się w domu.

\section{Charakterystyka narzędzia i próby badawczej}

W celu zgromadzenia danych umożliwiących udzielenie odpowiedzi na przyjęte problemy badawcze $\mathrm{z}$ instrumentu opracowanego w berlińskim projekcie ETiK Testu Kompetencji Moralno-Etycznej Piętnastolatków - został wyselekcjonowany zestaw zadań testowych uznanych za odpowiednie do kontekstu nauczania etyki i religii w Austrii. Na zestaw ten złożyło się 15 pytań-zadań odnoszących się do podstawowej wiedzy moralno-etycznej (PWM-E), 20 pytań-zadań z zakresu kompetencji sądzenia moralno-etycznego (KSM-E) i 15 pytań-zadań odnośnie do kompetencji projektowania działania moralno-etycznego (KPDM-E) ${ }^{5}$. Tak zbudowany instrument wzbogacono niewerbalnym testem inteligencji - Kognitives Fähigkeitstest (KFT 4-12+R; Heller, Perleth 2000), który miał dostarczyć informacji na temat ogólnego stopnia rozwoju zdolności myślenia uczestników badania.

W badaniu wzięło udział 617 osób, przy czym 87 respondentów wypełniło zestawy testowe w drugiej wersji. Zostaną one omówione poniżej przy sprawozdaniu z badania jakościowego. Tak więc do analizy wyników badania ilościowego zakwalifikowano 530 zeszytów z zadaniami, które wypełnili uczniowie i uczennice wybranych 11 gimnazjów Wiednia. Ze względu na płeć badana populacja dzieliła

${ }^{5}$ W tym referacie pominięte zostały kwestie dotyczące kompetencji religijnej. Przedstawiono je w: Ritzer i in. 2016. 
się na 56 proc. dziewcząt i 44 proc. chłopców. Inną cechą, która różnicowała uczestników badania, była liczba deklarowanych książek znajdujących się w biblioteczce domowej. Cecha ta stanowiła parametr określający bliskość respective oddalenie środowiska rodzinnego od sfery edukacji. Trzecim i ostatnim wskaźnikiem, do którego odwołano się w badaniu, był język najczęściej używany przez respondentów w komunikacji domowej.

W poniższej tabeli zestawiono dane uzyskane w trakcie badania. Tabela zawiera informacje uporządkowane w odniesieniu do każdej z 11 szkół, których uczniowie wzięli udział w rozwiązywaniu zadań testowych. Oprócz wymienionych powyżej trzech cech populacji - płeć, liczba książek i język, w drugiej kolumnie podano, czy w danym gimnazjum odbywają się lekcje etyki, czy też nie, w trzeciej natomiast, ile punktów uzyskali uczniowie w badaniu inteligencji z pomocą KFT. Odnośnie do tego ostatniego podano najpierw wartość punktową średniej arytmetycznej liczby punktów uzyskanych przez wszystkich uczniów danego gimnazjum (X), a następnie wartość punktową odchylenia standardowego (s).

Tabela 1. Charakterystyka populacji

\begin{tabular}{|c|c|c|c|c|c|c|}
\hline \multirow{2}{*}{ Gimnazjum } & \multirow{2}{*}{ Lekcje etyki } & \multicolumn{2}{|c|}{ KFT } & \multirow{2}{*}{$\begin{array}{c}\text { Język niemiecki } \\
\text { w domu (w proc.) }\end{array}$} & \multirow{2}{*}{$\begin{array}{l}\text { Liczba książek } \\
>100 \text { (w proc.) }\end{array}$} & \multirow{2}{*}{$\mathbf{N}$} \\
\hline & & $\mathrm{X}$ & $s$ & & & \\
\hline I & tak & 15,5 & 5,3 & 39 & 44 & 79 \\
\hline II & tak & 15,7 & 5,0 & 7 & 43 & 15 \\
\hline III & tak & 16,1 & 5,4 & 26 & 30 & 33 \\
\hline IV & nie & 17,0 & 5,3 & 79 & 72 & 43 \\
\hline $\mathrm{V}$ & tak & 17,3 & 5,2 & 89 & 82 & 48 \\
\hline $\mathrm{VI}$ & nie & 17,7 & 4,0 & 67 & 63 & 77 \\
\hline VII & nie & 17,8 & 4,1 & 82 & 76 & 17 \\
\hline VIII & tak & 18,0 & 5,0 & 53 & 75 & 65 \\
\hline IX & nie & 18,8 & 4,0 & 63 & 65 & 59 \\
\hline $\mathrm{X}$ & nie & 19,5 & 4,4 & 77 & 79 & 62 \\
\hline $\mathrm{XI}$ & tak & 22,8 & 1,6 & 70 & 100 & 23 \\
\hline Razem & $\begin{array}{c}6 \text { „tak” } \\
\text { vs } 5 \text { „nie” }\end{array}$ & 17,7 & 4,9 & 61 & 66 & 521 \\
\hline
\end{tabular}

Źródło: opracowanie własne.

Na podstawie zbliżonej liczby punktów za KFT podzielono szkoły na trzy grupy, a mianowicie: grupa A: gimnazja I-III, grupa B: gimnazja IV-VIII i grupa C: gimnazja IX-XI ${ }^{6}$. Podział ten umożliwił dokonanie analizy zgromadzonego materiału badawczego.

${ }^{6}$ Wskaźnik korelacji r-Pearsona dla testu KFT w stosunku do PWM-E wynosi o,32; w stosunku do KSM-E = o,43; w stosunku do KPDM-E = 0,25. Do wszystkich odnosi się p = o,oo1. 


\section{Charakterystyka kontekstu społeczno-kulturowego}

Na poniższym schemacie przedstawiono zmienne niezależne, $\mathrm{tj}$. wymienione na początku tego rodziału cechy służące do scharakteryzowania badanej populacji (płeć, liczba książek i język najczęściej używany w domu) w połączeniu ze średnią arytmetyczną liczby punktów uzyskanych przez respondentów posiadających daną cechę za rozwiązanie zadań testowych dotyczących kompetencji cząstkowych: PWM-E, KSM-E i KPDM-E. W przypadku wartości średnich różnicę wynoszącą mniej niż 20 punktów zinterpretowano jako małą moc efektu korelacji ${ }^{7}$. Im większa ta różnica, tym większa również zależność między zmiennymi niezależnymi a zakresami kompetencji moralno-etycznej. Z wyjątkiem średniej punktów uzyskanych przez uczniów i uczennice w zakresie PWM-E i KSM-E, wszystkie pozostałe różnice osiągnęły 95 proc. ufności obliczonej za pomocą statystyki t (t-Studenta), co świadczy o ich bardzo wysokim poziomie.

Wykres 1. Kompetencje cząstkowe (PWM-E, KSM-E i KPDM-E) a cechy populacji

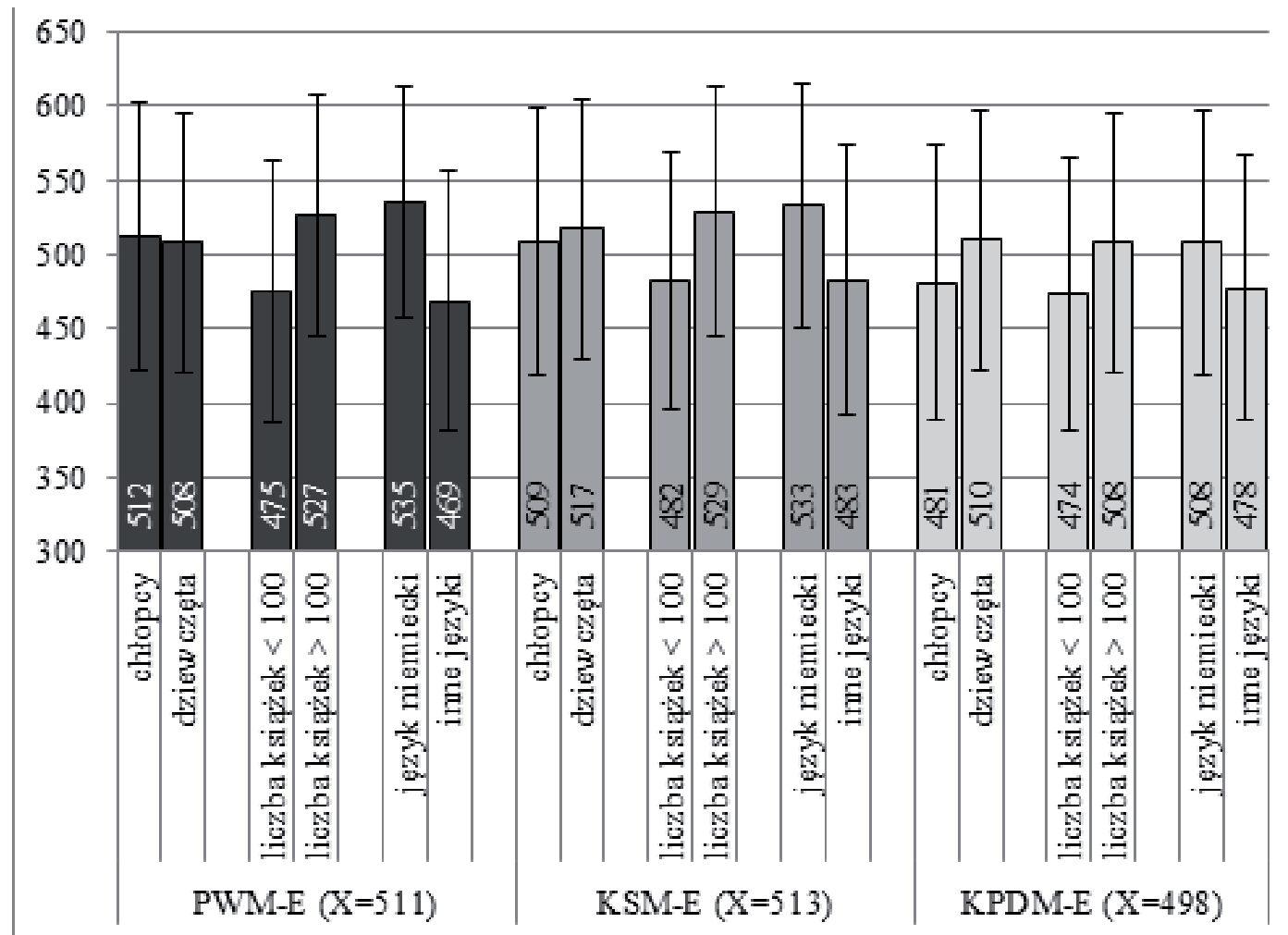

Źródło: opracowanie własne.

\footnotetext{
7 W obliczeniach przyjęto 100 punktów za wartość referencyjną odchylenie standardowego. A zatem różnica wynosząca 20 punktów odpowiada wartości efektu mierzonego z pomocą $d$-Cohena $=0,2$.
} 
Na powyższym schemacie widać wyraźnie, że największa dysproporcja między średnimi punktami uzyskanymi przez respondentów wystąpiła w odniesieniu do PWM-E ze względu na język dominujący w komunikacji rodzinnej $(\mathrm{X}=66 ; d=0,7)$. Za umiarkowane można uznać różnice, jakie wystąpiły w zakresie KPDM-E między respondentami ze względu na posiadane przez nich cechy $(0,4 \geq d \geq 0,3)$. Jeżeli chodzi o bliskość respective dystans środowiska rodzinnego do edukacji, który mierzono za pomocą deklarowanej liczby książek w biblioteczce domowej i dominującego języka w komunikacji rodzinnej, okazało się, że największe dysproporcje między respondentami pojawiły się w PWM-E i KSM-E, co dowodzi, że poziom oddziaływania tych cech na kompetencję moralno-etyczną waha się od średniego do dużego (o,7 $\geq d \geq 0,5)$.

\section{Kompetencja moralno-etyczna a uczestnictwo w lekcjach etyki}

Z przedstawionej w pierwszym rozdziale charakterystyki sytuacji prawno-organizacyjnej lekcji etyki respective lekcji religii w szkołach austriackich wynika, że możliwe są trzy sposoby zaangażowania uczniów w te przedmioty: 1) udział tylko w lekcjach religii; 2) udział tylko w lekcjach etyki (jeżeli są organizowane przez szkołę) i 3) nieuczestniczenie ani w lekcjach religii, ani w lekcjach etyki (dzieje się tak wówczas, gdy np. uczeń lub jego rodzicie/opiekunowie rezygnują z lekcji religii, a szkoła w swojej ofercie nie zapewnia nauczania etyki). W tym ostatnim przypadku uczniowie mają po prostu czas wolny.

W tym podrozdziale zostanie rozważone pytanie, czy uczniowie biorący udział w lekcjach etyki różnią się pod względem kompetencji moralno-etycznej od uczniów nieuczęszczających w te zajęcia, czy to $\mathrm{z}$ racji udziału w lekcjach religii, czy też nieuczestniczenia w żadnym z tych przedmiotów. W odniesieniu do uczniów biorących udział w lekcjach religii wprowadzono rozróżnienie ze względu na religię lub wyznanie.

Badając znaczenie średnich i różnic między nimi występujących ${ }^{8}$, okazuje się, że we wszystkich kompetencjach cząstkowych respondenci, którzy uczęszczają na lekcje religii muzułmańskiej, wykazują wyraźne niedomiary wobec swoich kolegów biorących udział, czy to w lekcjach religii, czy etyki, czy też nieuczestniczących $\mathrm{w}$ żadnym z tych przedmiotów ${ }^{9}$. Wyjątkiem w tym zakresie jest skala KPDM-E, w której uczestniczący w lekcjach etyki i w lekcjach islamu osiągają zbliżone wartości punktowe. Jeżeli jednak zwróci się uwagę na ogólną tendencję, która uwyraźnia się w poszczególnych zakresach kompetencji moralno-etycznej, to wyraźnie widać, że uczniowie biorący udział w katolickich lekcjach religii osiągnęli zbliżone wyniki do tych, które osiągnęli uczęszczający na lekcje etyki i nieuczęszczający ani na etykę, ani na religię. Ponadto rzucają się w oczy ponadprzeciętne wartości uzyskane przez uczestników ewangelickich lekcji religii. Ta konstatacja musi jednak uwzględnić niewielką liczebność tej grupy $(\mathrm{n}=16)$ w stosunku do całości

\footnotetext{
8 Obliczenie przeprowadzono, stosując analizę wariancji i test Scheffego $(\mathrm{p}<0,05)$.

9 Te niedomiary przekraczają połowę wartości odchylenia standardowego $(s>0,7)$.
} 
populacji (0,03 proc.). W tym kontekście warto podkreślić, że z przestawionych powyżej wyników nie należy wnioskować o jakości nauczania religii ani etyki. Poza tym różnice społeczno-kulturowe między uczniami są nazbyt wielkie, żeby takie wnioski mogły być kiedykolwiek słuszne.

Wykres 2. Kompetencja moralno-etyczna ze względu na uczestnictwo w lekcjach etyki

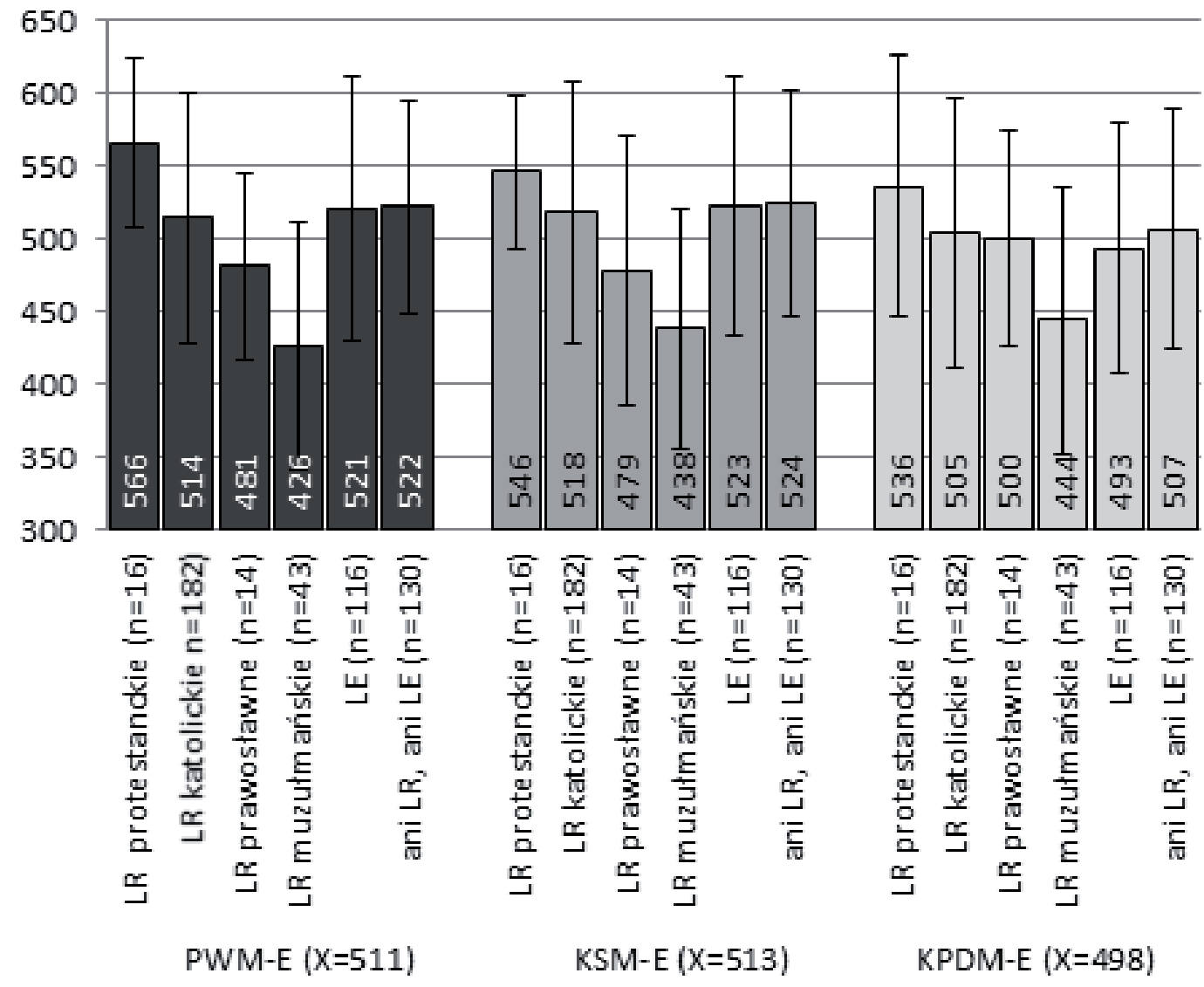

LR - lekcje religii; LE - lekcje etyki

Źródło: opracowanie własne.

\section{Wybrane wyniki badania jakościowego}

Celem drugiego rodzaju badania - jakościowego - było przede wszystkim poznanie sposobu argumentowania piętnastolatków. Nie było to możliwe w opisanym powyżej badaniu ilościowym, gdyż w zadaniach testowych rozróżniono jednoznacznie między odpowiedziami prawidłowymi i nieprawidłowymi. Co prawda, dzięki temu uzyskano „twarde” dane empiryczne na temat wskaźników psychometrycznych opisujących kompetencję moralno-etyczną respondentów, jednak nie dowiedziano się wiele odnośnie do motywów, którymi uczniowie kierowali się w swoich wyborach. Żeby 
temu mankamentowi zaradzić, wiedeński zespół ETiK-International przygotował drugą wersję zeszytu testowego. W wersji tej zrezygnowano z części zadań testowych na rzecz wypowiedzi pisemnych na temat przesłanek dokonanego wyboru. Tę wersję zeszytu testowego otrzymało 87 uczniów, którzy mieli do dyspozycji ten sam okres czasu na udzielenie odpowiedzi - dwie jednostki lekcyjne, jak ich koledzy, którzy odpowiadali, stawiając krzyżyk przy właściwej ich zdaniem odpowiedzi.

Przez zastosowanie podejścia jakościowego zespół z Wiednia chciał w szczególności uzyskać odpowiedź na pytanie o to, czy uczniowie rozważają problemy moralno-etyczne, dystansując się wobec własnej woli i jej dążeń; czy rozróżniają takie motywy działania, jak: życzliwość, prawość i słuszność; czy potrafią właściwie oddzielić od siebie i argumentacyjnie wyjaśnić poznane na lekcjach etyki formy myślenia etycznego, a mianowicie myślenie: aporetyczne, epagogiczne, teleologiczne, transcendentalno-kategoryczne, ideologiczno-krytyczne, społeczno-krytyczne i pragmatyczne.

Zasadnicza trudność, jaka ujawniła się po przeprowadzeniu badania, polegała na tym, że pisemne wypowiedzi uczniów były bardzo skąpe w słowa, a w przedstawionych uzasadnieniach operowali oni zwrotami zaczerpniętymi z języka potocznego, których związku z przedstawionym do rozstrzygnięcia problemem moralnym niejednokrotnie trudno było się dopatrzeć. Mimo to wydaje się, że można wydobyć z nich szereg interesujących stwierdzeń nastolatków, w których tok argumentacji moralno-etycznej zwraca się w całkowicie nieoczekiwanym kierunku. Anna Walchshofer i Janina Gmeiner w swoich niedokończonych jeszcze pracach magisterskich na WU podjęły się przeprowadzenia po opieką I.M. Breinbauer analizy tych wypowiedzi. Pierwsza ze studentek prześledziła racje przytaczane przez nastolatków dla uzasadnienia odpowiedzi na pytania testowe dotyczące godności ludzkiej. Przy tej okazji wykazała ona, że odnośnie do bardzo łatwego pytania z zakresu KPDM-E, na które przeważająca większość respondentów wypełniających zeszyt testowy odpowiedziała prawidłowo, tylko dwoje uczniów uznało w swoim uzasadnieniu godność człowieka za coś, co jest mu dane od chwili narodzin i czego nie wolno uzależniać od jakichkolwiek warunków wstępnych. Na podstawie pozostałych sposobów argumentowania można mieć uzasadnione wątpliwości, czy uczestnicy badania potrafili odróżnić fundamentalną i bezwarunkową godność człowieka od jej konkretnego przejawu. Wyjaśniając to, można oczywiście odwołać się do skali KPDM-E: na pierwszym jej poziomie wymaga się od uczniów „tylko” umiejętności identyfikowania czynów moralnych w konkretnych sytuacjach, znanych im z życia codziennego.

Innego, skrajnie przeciwstawnego przykładu, dostarcza analiza bardzo trudnego pytania z zakresu KSM-E (poziom IV), na które prawidłową odpowiedź zaznaczyło niewielu uczniów. Mimo to na podstawie uzasadnień, jakie podali do tego pytania, z niemałym zdziwieniem można skonstatować, że potrafią oni rozróżnić między religijną a etyczną legitymizacją godności człowieka i mają również wiedzę na temat wynikających z niej praw (np. prawo do życia, prawo do politycznego współuczestnictwa). Z całą pewnością nie udałoby się zarejestrować tych wyników, gdyby nie przeprowadzono badania jakościowego. 
W odniesieniu do wiedeńskiego badania ETiK-International należy stwierdzić, że jakościowa analiza wypowiedzi uczestników dostarczyła nowych impulsów do interpretacji danych uzyskanych w badaniu ilościowym. Na tej podstawie można sformułować tezę, że w przypadku kompetencji moralno-etycznej nie wystarcza sprawdzenie wiedzy i umiejętności uczniów, lecz trzeba poznać również sposób, w jaki obchodzą się oni z pytaniami i odpowiedziami zawartymi w zadaniach testowych.

\section{Podsumowanie i wnioski na przyszłość}

W wiedeńskim badaniu ETiK-International wzięli udział uczniowie i uczennice, którzy z zróżnicowanej formie uczestniczą w lekcjach etyki respective religii (różnych religii i wyznań) oraz nie uczestniczą w lekcjach z żadnego z tych przedmiotów. Taka struktura badanej populacji pozwoliła na wyodrębnienie kompetencji kształtowanych na zajęciach lekcyjnych w szkole i poza szkołą. Przede wszystkim jednak określono efekty nauczania etyki i religii jako odrębnych przedmiotów szkolnych. Pełne porównanie lekcji etyki i religii zostało uniemożliwione przez zbytnią dysproporcję liczebności uczniów uczestniczących w tych zajęciach. W każdym razie porównanie wyników osiągniętych przez uczniów uczestniczących w szkolnym nauczaniu etyki i tych, którzy w nim nie uczestniczą, należy uznać za wynik zaskakujący. Zgromadzone dane wskazują bowiem na to, że na kształt kompetencji moralno-etycznej znacznie większy wpływ mają czynniki społeczno-kulturowe niż nauczanie szkolne. W tym kontekście powstaje pytanie, w jakim stopniu może to być skutkiem braku trwałego zakotwiczenia etyki w systemie edukacyjnymi w Austrii i prowadzenia zajęć z tego przedmiotu wyłącznie w formie eksperymentu szkolnego, co oznacza brak jednolitego programu nauczania i kryteriów ewaluacji. Pytanie to należy dokładniej przeanalizować. Poza tym wydaje się, że przeprowadzone w Wiedniu badanie dostarczyło w części jakościowej dowodów na potrzebę zweryfikowania zrozumiałości pytań stawianych w zadaniach przygotowanych w berlińskim Teście Kompetencji Moralno-Etycznej Piętnastolatków. Przy tej okazji należy stwierdzić, że „moc” odpowiedzi austriackich uczniów w zakresie kompetencji moralno-etycznej jest ograniczona, dlatego że wzięli w nim udział wyłącznie mieszkańcy austriackiej stolicy. Być może w przyszłości uda się przeprowadzić badanie o zasięgu ogólnokrajowym, w którym uwzględnione zostaną różnice między poszczególnymi regionami Austrii.

\section{Przettumaczył z języka niemieckiego Dariusz Stępkowski}

\section{Bibliografia}

Benner D. (2014a). Zur Bedeutung allgemein-pädagogischer Theoriebildung für die Konzeptualisierung erziehungswissenschaftlicher Forschung. W: U. Dopplinger, 
S. Gabriel, Th. Krobath, I. Kromer, D. Lindner, G. Ritzer (red.). Forschen an der KPH Wien/Krems: Tag der Forschung 2013. Wien: LIT Verlag, s. 21-50

Benner D. (2014b). Bildung und Religion. Nur einem bildsamen Wesen kann ein Gott sich offenbaren. Paderborn-München-Wien-Zürich: Schöningh.

Benner D., Nikolova R., Swiderski J. (2009). Die Entwicklung moralischer Kompetenzen als Aufgabe des Ethik-Unterrichts an öffentlichen Schulen. Zur Konzeption des DFG-Projekts ETiK. „Vierteljahrsschrift für wissenschaftliche Pädagogik", nr 85, s. 504-515.

Benner D., Schieder R., Schluss H., Willems J. (2011). Religiöse Kompetenz als Teil öffentlicher Bildung. Paderborn-München-Wien-Zürich: Schöningh.

Benner D., von Oettingen A., Peng Z., Stępkowski D. (2015). Bildung - Moral Demokratie. Theorien und Konzepte moralischer Erziehung und Bildung und ihre Beziehungen zu Ethik und Politik. Paderborn-München-Wien-Zürich: Schöningh.

Bucher A.A. (2001). Ethikunterricht in Österreich. Innsbruck: Tyrolia.

Bucher A.A. (2014). Der Ethikunterricht in Österreich. Politisch verschleppt, pädagogisch überfällig. Innsbruck: Tyrolia.

Ethikunterricht: Klare Position der katholischen Kirche. www.schulamt.at/index. php/aktuelles/pressespiegel/746-ethikunterricht-klare-position-der-katholischen-kirche (otwarto 14.07.2015).

Heller K.A., Perleth C. (2000). Kognitiver Fähigkeitstest für 4. bis 12. Klassen, Revision. KFT 4-12+. Göttingen: Beltz-Test.

Philosophisch-religiöse Bildung als Aufgabe der Schule? Dostępny na: https://kalender.univie.ac.at/einzelansicht/?tx_univieevents_pi1\%5Bid\%5 D=10820\&tx_umiv eevents_pi1\%5Bday\%5D=21\&tx_univieevents_pi1\%5Bmonth\%5 $\mathrm{D}=01 \&$ tx_univieevents_pi1\%5Byear\%5D=2015 (otwarto 14.07.2015).

Ritzer G., Breinbauer I.M., Schluss H., Krobath Th. (2016). Die Erprobung eines Instrumentariums zur Überprüfung ethischer und religiöser Kompetenzen an Wiener Gymnasien. ETiK Wien - Erste Ergebnisse. W: D. Lindner, Th. Krobath, S. Gabriel, R. Rudolf (red.). Dialog Forschung. Tag der Forschung 2015. Wien: LIT, s. 26-43.

Schluss H. (2010). Religiöse Bildung im offentlichen Interesse. Analysen zum Verhältnis von Pädagogik und Theologie. Wiesbaden: VS Verlag.

Schluss H. (2011). Religiöse Bildung als religiöse Kompetenz und ihr Bezug zu Wertefragen. W: M.-L. Raters (red.). Werte in Religion und Ethik. Modelle des Werteunterrichts in Deutschland, Österreich und der Schweiz im kritischen Vergleich, Dresden: Thelem, s. 159-176.

Schmied C. (2012). Bericht der Bundesministerin für Unterricht, Kunst und Kultur gemäß Entschließung des Nationalrates vom 19.01.2012 betreffend Ethik-Unterricht (221/E XXIV.GP). Dostępny na http://fdz-pp.univie.ac.at/fileadmin/user_upload/ fd_zentrum_philosophie/bericht_bmukk.pdf (otwarto 14.07.2015).

Schulorganisationsgesetz, Dostępny na: https://www.ris.bka.gv.at/GeltendeFassung. wxe? Abfrage $=$ Bundesnormen $\&$ Gesetzesnummer $=10009265$ (otwarto 14.07.2015). 
Universitätslehrgang 'Ethik'. Dostępny na http://philosophie.univie.ac.at/fb2/ethik-lehrgang/ (otwarto 14.07.2015).

\title{
ETIK-INTERNATIONAL STYDY IN VIENNA. RESEARCH PROBLEMS, THE STUDY AND ITS RESULTS
}

\begin{abstract}
Ethics in Austria, like in the majority of European countries, is an alternative subject for Religious Education in the public school education system. Although this situation has lasted for more than two decades now, there is no social or political initiative to change it. This article presents the ETiK International study which was carried out in Vienna in 2014 by a team of scientists from Wiener Univeristät and Kirchliche Pädagogische Hochschule Wien/Krems.

This article consists of four parts. The first offers a description of the legal as well as the social and cultural determinants of teaching Ethics and Religious Education in Austria. The second chapter introduces the research problems studied in the ETiK-International project. The last two chapters discuss the quantitive results (third one) and qualitative results (fourth) obtained in eleven high schools in Vienna.
\end{abstract}

Keywords: ETiK-International, moral and ethical skills, qualitative study, quantitive study.

Georg Ritzer - doktor habilitowany, zatrudniony w Uniwersytecie w Salzburgu, na Kirchliche Pädagogische Hochschule w Salzburgu i Wiedniu. Zainteresowania badawcze: badania pedagogiczne, empiryczna pedagogika religii, teoria kształcenia. Autorskie publikacje książkowe: „Reli oder Kaffeehaus” (2003), Interesse-Wissen-Toleranz-Sinn (2010), Adres majlowy: georg.ritzer@kph-es.at.

Ines Maria Breinbauer - doktor habilitowany, emerytowany profesor Uniwersytetu Wiedeńskiego (Austria). Zainteresowania badawcze: pedagogika ogólna, metodologia badań pedagogicznych, teoria kształcenia, pedagogika mediów i dydaktyka akademicka. Autorskie publikacje książkowe: Erwachsenenbildung und Medienverbund (1977), Erziehung in der Schule (1980), Erziehung und Sozialisation in der Schule (1982), Der Respekt vor dem Subjekt - Studien zu Theorie und Lehrbarkeit der Erziehung (1982), Einführung in die Allgemeine Pädagogik (1999). Adres mejlowy: ines.maria.breinbauer@univie.ac.at.

Henning Schluss - doktor habilitowany, profesor Uniwersytetu Wiedeńskiego (Austria), kierownik Katedry Teorii Kształcenia i Badań Edukacyjnych. Zainteresowania badawcze: relacja między teorią kształcenia a badaniami edukacyjnymi. Autorskie publikacje książkowe: Lernplanentwicklung in den neuen Ländern - nachholende Modernisierung oder reflexive Transformation? (2003), Der Mauerbau im DDR-Unterricht (2005), Religiöse Bildung im öffentlichen Interesse (2010), razem z: D. Benner, R. Schieder, J. Willems - Religiöse Kompetenz als Teil öffentlicher Bildung (2011). Adres majlowy: henning.schluss@univie.ac.at.

Thomas Krobath - doktor pedagogiki, prorektor Kirchliche Pädagogische Hochschule Wien/Krems. Adres majlowy: thomas.krobath@kphvie.ac.at 